\title{
Color Component in Ethnophobic Terms Denoting East Asians and People of Muslim Confession (the case of non-standard American English)
}

\author{
T. Pastushenko, I. Honta \\ Taras Shevchenko National University of Kyiv, Kyiv, Ukraine \\ Corresponding author. E-mail: tatiana.v.pastushenko@gmail.com, ihonta@ukr.net \\ orcid.org/0000-0002-8784-4059
}

Paper received 28.10.19; Accepted for publication 15.11.19.

\section{https://doi.org/10.31174/SEND-Ph2019-211VII62-08}

\begin{abstract}
The article deals with ethnophobic terms used in non-standard American English to denote East Asians and people of Muslim confession. Our research focus has been on the functions of color components in the semantics and structure of ethnophobic terms. The role of the color component in the formation of ethnicity-laden expressions is based on its semantic, pragmatic, and conceptual dimensions. The linguistic mechanism underlying the derivation of ethnophobic terms is revealed through the description of their structural and word-forming characteristics. In our investigation, account is taken of the extralinguistic factors in the formation of ethnicity-laden expressions, the issue of their political correctness and cautious use being of special importance.
\end{abstract}

Keywords: ethnophobic terms, color component, non-standard language, metaphor, metonymy.

Introduction. The last centuries have been marked by rapid expansion of globalization, involving the spheres of science, industry, business, and culture. Lack of understanding, tolerance and acceptance in the intensive crosscultural communication, either peaceful or belligerent, has resulted in engendering a constantly growing number of ethnophobic terms focusing on the allegedly "negative" features associated with different racial and ethnic groups. Despite the Monroe Doctrine policy dating as far back as 1823, the USA has been involved in globalization processes around the world, including the countries of the Middle East as well as Southeast Asia. Obviously, the complicated, often double-edged, economic, cultural and political relationship between the U.S. and the Asian and African countries may account for the fact that originally neutral ethnic names were often dubbed with numerous ethnophobic terms, or ethnic slurs, the role of the English language as a lingua franca having largely contributed to their wider spread. On the other hand, the Englishspeaking community is well aware of the international strategies for reducing racial prejudice, promoting political correctness, treating members of all ethnic groups with equal respect, and avoiding derogatory nominations. It is therefore generally agreed that ethnophobic terms should be used with extreme caution or preferably avoided.

Given their social background, ethnophobic terms tend to be used in a non-formal environment and, contrary to popular belief, are not necessarily intended as an insult. In their attempt to make an impression or create a relaxing atmosphere, members of a friendly community may resort to this less exquisite vocabulary, choosing this as a means of boasting their sense of humor rather than sounding ironic or sarcastic. Making no excuses for their purposefully derogatory use or even unconscious bias, scholars take a theoretical interest in ethnophobic terms as structurally diverse, semantically expressive language units, as well as unique containers of social, cultural, and historical information concerning diverse ethnic groups. Of special interest are the terms incorporating a color component, which significantly contributes to their semantics.

A brief review of publications on the subject. Ethnophobic terms have been a focus of research in Ethnoliguistics, a branch of Linguistics concerned with the relation- ship between language and culture, the interrelation between linguistic and ethnic factors in language functioning and development [5, p. 530]. Ethnophobic vocabulary is linked to the notion of stereotype, whose formation is determined by identifying and contrasting those features which are interpreted by an ethnic majority as "atypical". These commonly include appearance and physical characteristics of people belonging to ethnic minorities [7, p. 7]. Stereotypes are also defined as the set of values, attitudes and behaviors shared by a group and passed on from generation to generation $[10, \mathrm{p} .68]$. An essential feature of ethnophobic terms is their negative axiological load based on a derogatory, sometimes even hostile, attitude to minority ethnic groups [6, p. 103]. Ethnophobic terms, whose growing number might be due to ineffective intercultural communication [13], are closely related to ethnophobia, a socially and historically constructed extralinguistic phenomenon ranging from inter-ethnic unease to ethnic cleansing [12, p. 271].

Ethnophobic terms as a part of ethnic nomenclature have been studied in cognitive, onomaseological and functional contexts [7]. Ethnic and ethnophobic terms denoting Latin Americans in the USA have been classified into categories based on the negative emotions conveyed [1]. Various other aspects of ethnicity-laden expressions have also been identified as research problems: ethnobpobic terms belonging to the semantic field of "war" [2]; the problem of translating ethnophobic terms [4]; ethnophobic terms as linguistic realization of national and cultural prejudice [11], in particular, in the UK [5]. Recent research has also focused on the extralinguistic factors in coining ethnophobic terms in American nonstandard vocabulary [3].

Ethnophobic terms with color components have been thoroughly investigated; however, the scope of research was limited to non-standard American expressions denoting three most numerous ethnic groups in the USA: Black, Latin and Native Americans [14].

The semantic potential of colors is actively engaged in the formation of non-standard English words and expressions, giving rise to new conceptual blends based on color associations. Color is unique and even paradoxical in its capability of combining the ontological opposites, e.g. being both objective and subjective, discreet and continu- 
ous, abstract and concrete, universal and specific [14, p. 227]. Such a complicated nature of color may account for the variability and diversity in its understanding, conceptualizing, and verbalizing. Although the evolution of color conceptualization and referring prime colors to linguistic universals remain controversial issues [16, p. 13], the conceptual and semantic dominance of the color categories black, white and red seems to persist. The crosscultural symbolic affinity of the three basic color terms may have been extrapolated from the universal physiological cycle, where white is associated with life, black with death, and red - with both (through blood) [18, p. 151].

The spectrum of meanings conveyed by color components in the non-standard vocabulary is immensely diverse, mostly due to intricate combinations of extralinguistic factors in the historical and cross-cultural evolution of American society.

Methods and materials. Ethnophobic terms (also referred to as ethnic slurs) were selected from both online and paper dictionaries of American non-standard English. The terms contain a color component in their semantics and/ or morphological structure and denote people of East Asian origin, as well as people of Muslim confession who come from Africa or Asia. The bulk of the language material being general slang words easily recognized by American English speakers, the etymology is often overwhelmingly transparent. As has been pointed out, connotation tends to prevail over the denotative meaning in the terms under study, which are often used to express derogation, frustration, or even verbal abuse, especially taboo words [15]. The scope of the study is restricted to ethnophobic terms denoting people of East Asian origin and Muslim confession (mostly Arab descent), who constitute an essential part of American ethnic minorities.

In our research, we combined analysis of dictionary definitions with structural, semantic, conceptual, comparative, and linguacultural analyses.

The corpus of the investigated terms was first divided into two groups (East Asians and Muslims); subgroups based on the color component (referring to a certain color category) were then singled out in each of the groups. The semantic and structural peculiarities of the words/ phrases were analyzed, described and interpreted, with a special focus on the extralinguistic (social, historical and cultural) environment that underpins the etymology of the words and helps to reveal their semantic and pragmatic value.

This research aims to identify the role of the color component in the coinage of ethnophobic terms denoting East Asians and Muslims in American non-standard English, based on a thorough analysis of their semantic, structural, word-forming characteristics and the extralinguistic factors that underlie their semantics and pragmatics.

Results and discussion. Compared to Afro- and Latin Americans, people of East Asian descent are a less numerous racial minority in the USA, making $6.8 \%$ of the total U.S. population, according to the 2017 census [26]. Yellow, white, black and red are the color components identified in the structure of the terms denoting Asians, of which yellow, associated with the color of the skin, is overwhelmingly predominant: Banana - an Asian American who has lost his/her heritage [25]. Peeled bananas (yellow on the outside and white on the inside) are Amer- icanized Asians who are trying to adapt to the culture of the white (RSDB). Jaundy boy comes from Jaundice (Hepatitis), which turns skin yellow [25]; lemonhead and pancake are metaphors based on the association with the shape and color of the face. In the words yellow, yellow devils and yellow monkeys the explicit color category is an evident metonymy combined with metaphoric components devils and monkeys. The origin of Yellow peril dates as far back as 1895, when the Treaty of Shimonoseki completed the first Sino-Japanese war, after which Germany, France and Russia intervened, compelling Japan to surrender some of their territorial claims (the Liaodong peninsular) to Russia. It was the German Kaiser Wilhelm II who used the term die Gelbe Gefahr, calling the European countries to repulse the non-existent geopolitical dangers of the "yellow race" against the "white race". The term die Gelbe Gefahr was soon borrowed by other Europeans and Americans: le peril jaune (in French), Yellow peril [27]. In the following decades the USA waged war against Japan (1941-1945), Korea (1950-1953), and Vietnam (the war ended in 1975). Sadly, hostility brought about by these and other political events of less dramatic consequences contributed to engendering numerous ethnophobic terms, including those containing a color component.

Other skin-color-based metaphorical denominations of Asians include the words yolk and Simpsons, the famous yellow-skinned cartoon characters [25].

Rasian (red+asian) is used to describe Asians who drink and turn red [25]. The color black implied by the derogatory word nigger is also used to denote Asians: rice nigger - because of their staple food; squint nigger scornfully describes slanting eyes; Japanniger (Japan+Nigger) describes Asians of unknown origin [25]. $\mathrm{SBH}$ is an acronym standing for Straight Black Hair, which is selfexplanatory [25].

According to their morphology, ethnophobic terms denoting people of Asian origin are predominantly compounds, blends, and phrases, which accounts for their ability to render a wealth of historical and socio-cultural information, as well as negative axiological connotation within a concise morphological structure.

Our research results suggest that the color category yellow(ish) associated with the color of skin dominates as the conceptual basis for coining ethnophobic terms to denote the Asians in American slang. The few exceptions are combinations with the word nigger, whose original denotative meaning "black" has been erased, nowadays only retaining its derogatory semantics.

Despite the fact that people of Arab descent make up only 1.2 percent of the overall U.S. population, [28], numerous ethnophobic terms with a color component have been generated to denote this ethnic group. Since the 18th century, American culture has created sundry images of Arab Muslims depicting them as backward, aggressive and Muslim women as submissive and weak. With resentment stemming from the stereotypes, American writers are criticized for depicting Arabs as animal-like nomads, potential criminals, irrational, untrustworthy, and anti-American [9, p. 26]. Coining a large number of slur words and collocations denoting Arabs is often associated with American geopolitical interests in the Arabic speaking countries, wars, conflicts, and terrorist attacks rather 
than the small Muslim minority living in the USA. Moreover, the negative image of Arabs is fostered by regular news portraying Muslims as terrorists, which contributes to Americans' support for military actions in Muslim countries [17, p. 841].

The black color has been found to dominate the semantic structure of ethnophobic terms denoting Arabs, many of which contain the word nigger, although its offensive derogatory connotation prevails over the (partially) erased denotation of the color proper. As the word nigger originally indicated Africans or people of African origin, it can only denote Arabs when combined with other components that differentiate and particularize the semantics of the compounds, blends and phrases: cave nigger refers to Osama Bin Laden hiding from Americans [25]; deminigger - somewhat lighter skin tone than Blacks [25]; sand nigger - arab (RSDB). In these examples, the word nigger remains the central semantic component, while the modifying word or element restricts its meaning. Snigger is a blend of sand and nigger [25]. Glass nigger comes from the suggestion that if atomic weapons were to go off, sand niggers would become glass niggers [25]. In the acronym BMO (Black Moving Object) the color component metonymically refers to the complete head-to-toe black dress of Muslim women.

Other color categories used to denote Arabs are brown and grey: peanut butter brother refers to the color of peanut butter, believed to resemble the skin color of Arabs [25]; the word mocha implies the color of a kind of coffee originally grown in Arabia, which is lighter brown and also resembles Arabs' skin color [25]. The term dirty knees is associated with the daily Muslim praying on their knees [25].

Overall, the same tendency can be observed of combining metonymy, metaphor or both with morphological derivation, mostly compounding and blending. Multiple word-forming devices employed to coin ethnophobic terms create a variety of connotations based on extralinguistic information. The derogatory component nigger tends to convey a negative attitude toward Arabs, while the other color categories involved in word derivation are those associated with skin and / or clothes.

Conclusions. Our research results showed that the semantic component of color is highly prolific in the formation of ethnophobic terms and is capable of conveying a wide range of cultural, historical, and social information about ethnic groups, both visible and recondite. Although the modern concept of ethnicity is based on shared cultural heritage rather than biological traits, it is due to their external characteristics that these ethnic groups may still be regarded as "strangers" by Americans of European descent. The color component can be employed metonymically or metaphorically (or both), either independently or simultaneously with morphological word formation (compounding, blending, abbreviation, and affixation). The color category yellow is commonly used as conceptual basis to coin words denoting East Asians. The racist slur nigger is highly productive and often used to coin ethnophobic terms denoting not only Afro-Americans, but Arabs and East Asians as well. However, in many compounds nigger, which is used as an onomaseological basis specified by a modifier, only retains a derogatory or abusive connotation, while the denotative meaning (color category black) has been partially or entirely erased. Both transparent and clandestine semantics of ethnophobic terms encodes cultural, political, and social information that accounts for the word motivation. Most importantly, being verbal expression of phenotypic differences and a form of embodied racism likely to cause abuse in intercultural communication, ethnophobic terms are best avoided.

\section{ЛІТЕРАТУРА}

1. Гладких О.И. Особенности этнономинаций в американском варианте английского язика (на примере иммигрантов из Латинской Америки) / О.И. Гладких, О.Н. Демидец // Ученые записки Крымского федерального университета имени В.И. Вернадского. Филологические науки. Симферополь: Крымский федеральный университет имени В.И. Вернадского. - 2015. - С. 180-183.

2. Гонта I.А. Соціально-історична мотивація американських етнофобізмів лексико-семантичного поля «війна» // Стиль і переклад. Збірник наукових праць. Випуск 1(5). Київ: ВПЦ «Київський університет», 2018. - С. 141-152.

3. Гонта I.A. Екстралінгвістичні чинники в утворенні етнофобізмів в американському мовному субстандарті // Науковий вісник Херсонського державного університету. Серія Перекладознавство та міжкультурна комунікація. Випуск 1. - Херсон: Видавничий дім «Гельветика», 2018. C. $31-36$

4. Гонта I.А. Переклад стилістично-маркованих номінативних одиниць на позначення рас та національностей / I.A. Гонта // Науковий часопис Національного педагогічного університету ім.. М.П. Драгоманова. Серія 5. Педагогічні науки: реалії та перспективи. Випуск 49. - К.: Вид-во НПУ ім. М.П. Драгоманова, 2014. - С. 63 - 66.

5. Кущ Е.О. Національно-культурна специфіка лінгвальної реалізації етнічних упереджень у Великобританії / Е.О. Кущ // Мова, мовлення, мовна комунікація. Матеріали VIIМіжнародної науково-практичної конференції «Наука

і освіта 2004». Серія: Філологічні науки. - Дніпропетровськ: Наука і освіта, 2004. - Том 26. - С. 49-51.

6. Лютянська Н.I. Відтворення ситуацій міжетнічної взаємодії у мас-медійних британських та американських дискурсивних практиках. Дис. ... канд. філол. наук: 10.02.04 / Н.І. Лютянська. - Миколаїв, 2017. - 219 с.

7. Святюк Ю.В. Семантика та функціонування етнономінацій у сучасній англійській мові: Дис. ...канд. філ. наук: 10.02.04 / Ю.В. Святюк. - К., 2005. - 258 с.

8. Святюк Ю.В. Етнічна единтичність та національна толерантність у англійській мові // Лінгвістичні дослідження. № 39. - Харків: Харківський національний педагогічний університет імені ГС Сковороди, 2015.- С. 182-187.

9. Altwaiji, M. American Orientalist Discourse: the Linguistic Formation and Transformation. International Journal of English Linguistics, 1, 9, 2019. - P. 261-268.

10. Davies, E. (2003). A Goblin or a Dirty Nose? The Treatment of Culture-specific References in Translations of Harry Potter. The Translator, 6, 65-100. Retrieved from https://doi.org//10.1080/13556509.2003.10799146

11. Dijk T.A. Prejudice in discourse: An analysis of ethnic prejudice in cognition and conversation / Dijk T.A. - Amsterdam: Benjamins, 1984. - $294 \mathrm{p}$.

12. Embree, L. American Ethnophobia, e.g., Irish American in Phenomenological Perspective. Human Studies, 20, 2, 1997. - P. 271-286.

13. Habke, A. \& Sept, R. Distinguishing group and cultural influences in interethnic conflict: a diagnostic model. Canadi- 
an Journal of Communication. Retrieved September, 12 from http://www.cjc-online.ca/index.php/journal/article/ view/773/679

14. Honta, I., Pastushenko, T., Borysenko, N. Color Component in the Semantics of Ethnophobic Terms // Advanced Education. Новітня освіта. Випуск 12. - Київ: КПІ імені Ігоря Сікорського, 2019. - С. 226 - 236.

15. Jay, K. \& Jay, T. Taboo word fluency and knowledge of slurs and general pejoratives: deconstructing the poverty-ofvocabulary myth. Language Sciences, 52, 251-259. Retrieved from https://doi.org/10.1016/j.langsci.2014.12.003
16. Jones, W. J. German Color Terms: A Study in their Historical Evolution from Earliest Time to the Present. Amsterdam/ Philadelphia: John Benjamins Publishing Co, 2013.

17. Saleem, M., Prot S., Anderson, C., Lemieux, A. (2015, December 9). Exposure to Muslims in Media and Support for Public Policies Harming Muslims. Communication Research, 44, 841-869. Retrieved from https://journals.sagepub.com/ doi/abs/10.1177/0093650215619214

18. Turner, V. Symbolic Studies. Annual Review of Anthropology, 1075. - P. 145-161

\section{ДЖЕРЕЛА ІЛЮСТРАТИВНОГО МАТЕРІАЛУ}

19. Spears, R.A. Dictionary of American Slang and Colloquial Expressions. Lincolnwood: National Textbook Company, Illinois, USA, 1991.

20. UT. Urban Thesaurus [Electronic dictionary]. https://urbanthesaurus.org/

21. Wentworth, H. \& Flexner, S. Dictionary of American Slang. New York, USA: Thomas Y. Growell Publishers, 1975

22. YDcom. YourDictionary.com. UC Santa Barbara Library [Electronic dictionary]. https://www.library.ucsb.edu/ research/db/1019

23. Merriam-Webster's Dictionary. [Electronic dictionary]. https://www.merriam-webster.com/dictionary
24. English Oxford Living Dictionaries. [Electronic dictionary]. https://en.oxforddictionaries.com

25. The Racial Slur Database Dictionary [Electronic dictionary]. http://www.rsdb.org.

26. Asian Americans [Electronic resource]. https://en.wikipedia.org/wiki/Asian_Americans./

27. Yellow peril. [Electronic resource]. https://en.wikipedia.org/wiki/Yellow_Peril\#Origin

28. Arab immigration to the United States. [Electronic resource]. https://en.wikipedia.org/wiki/Arab_immigration_to_the_Unit ed_States.

\section{REFERENCES}

1. Hladkih O.I. Pecularities of ethnic terms in American variant of the English language // Scientific Notes of Vernadsky Crimean Federal University. Phililogical Sciences. - Simferopol: Vernadsky Crimean Federal University. - 2015. - C. 180-183.

2. Honta I.A. Translation of stylistically marked words denoting races and nationalities // Scientific Journal of Drahomanov National Pedagogical University. Pedagogical Sciences: Realities and Prospects. Issue 49. - Kyiv: Drahomanov University Publishers, 2014. - P. 63-66.

3. Honta I.A. Social and historical motivation of American ethnophobic terms belonging to semantic field 'war' / Style and Translation. Issue 1(5). - Kyiv: Kyivsky University Publishers, 2018. - P. 31-52.

4. Honta I.A. Extralinguistic motives in creating ethnophobic terms in American non-standard language // Scientific Herald of Kherson State University. Issue 1. - Kherson: Helvetyka Publishers, 2018. - P. 31-36.

5. Kusch Ye.O. National and cultural peculiarities of verbal realization of ethnic prejudice in Great Britain // Language, Speech, Language Communication. Materials of the 7th International Scientific Conference 'Science and Education'. Philology. - Dnipropetrovsk: Nauka i Osvita Publishers, 2004. - Volume 26. - P. 49-51.

6. Liutianska N. (2017). Reproduction of situations of interethnic interaction in mass media British and American discourse practice. Unpublished candidate dissertation, Petro Mohyla Black Sea National University, Mykolaiv, Ukraine, 2017.

7. Sviatyuk, Yu.V. Semantics and functioning of ethnic terms in the modern English language. Unpublished candidate dissertation, Donetsk National University, Donetsk, Ukraine, 2005.

8. Sviatyuk Yu.V. Ethnic identity and national tolerance in English // Linguistic Studies. Issue 39, 2015. - P. 182-187. 